\title{
5-Aminosalicylic Acid-Associated Myocarditis and Pericarditis: A Narrative Review
}

\author{
Glen Brown
}

\begin{abstract}
Background: Use of medications containing the 5-aminosalicylic acid (5-ASA) moiety may cause a rare but potentially lethal side effect involving inflammation of the heart (myocarditis) or pericardium (pericarditis) or both (myopericarditis). Early recognition of 5-ASA as the cause is important to prevent progression of the inflammation.

Objective: To provide clinicians with information to assist in recognizing the signs and symptoms of 5-ASA-induced cardiac inflammation and the characteristics of the suspected therapy, and in determining the appropriate approach to treatment.

Data Sources, Study Selection, and Data Extraction: The Embase database was searched, for the period 1974 to July 17, 2015, for published descriptions of cases of cardiac inflammation caused by 5-ASA-containing medications. The search terms included the names of specific agents, as well as terms for different types of cardiac inflammation. Articles in any language were retained for inclusion in this narrative review.

Findings: There is no symptom, sign, laboratory test, or constellation of symptoms and signs that is pathognomonic for 5-ASA-induced myocardial-pericardial toxicity. Similarly, there is no single laboratory, electrocardiographic, or echocardiographic finding or combination of findings that implicates 5-ASA as the cause of nonspecific symptoms. However, most patients present with chest pain, shortness of breath, and fever within the first 28 days after initiating 5-ASA. Physical examination, electrocardiography, and diagnostic imaging will yield findings consistent with myocarditis, with or without accompanying pericarditis. Prompt discontinuation of the 5-ASA will result in resolution of symptoms within days, without the need for any adjunctive therapies. Rechallenge with any 5-ASA-containing compound carries a high risk for recurrence of the inflammation.
\end{abstract}

Conclusions: Any patient presenting with chest pain, shortness of breath, or fever within 28 days after initiating a 5-ASA-containing drug should be considered as exhibiting drug-induced inflammation. The 5-ASAcontaining drug should be stopped immediately until other causes can be proven (or excluded); if no other cause is discovered, the 5-ASA should not be restarted.

Keywords: 5-aminosalicylic acid, mesalamine, mesalazine, myocarditis, pericarditis

Can J Hosp Pharm. 2016;69(6):466-72

\section{RÉSUMÉ}

Contexte : L'emploi de médicaments à base d'acide 5-aminosalicylique (5-AAS) peut causer un effet indésirable rare, mais potentiellement mortel qui se traduit par l'inflammation du myocarde (myocardite) ou du péricarde (péricardite) ou de ces deux éléments du système cardiaque (myopéricardite). Il est important d'établir rapidement que l'inflammation est imputable à l'AAS afin de prévenir la progression de cet effet indésirable.

Objectif : Fournir aux cliniciens de l'information les aidant à reconnaitre les signes et symptômes d'une inflammation cardiaque causée par le 5-AAS et les caractéristiques de la thérapie soupçonnée ainsi qu’à déterminer l'approche thérapeutique adéquate.

Sources des données, sélection des études et extraction des données : La base de données Embase a été interrogée, pour la période allant de 1974 au 17 juillet 2015, afin de trouver des descriptions publiées de cas d'inflammation cardiaque causée par des médicaments contenant du 5-AAS. Les termes utilisés pour la recherche comprenaient les noms d'agents précis ainsi que les termes désignant différents types d'inflammation cardiaque. La langue n'était pas un critère pour l'admissibilité des articles à la présente revue narrative.

Résultats : Il n'y a pas de symptôme, de signe, d'examen de laboratoire ou de cortège de symptômes et de signes qui soit pathognomonique d'une toxicité myocardique ou péricardique causée par le 5-AAS. De même, il n'y a pas de résultat de laboratoire, d'électrocardiogramme ou d'échocardiogramme, seul ou en association, qui puisse attribuer la cause de symptômes non spécifiques au 5-AAS. Cependant, la plupart des patients présentent des douleurs thoraciques, une dyspnée et de la fièvre au cours des 28 premiers jours suivant l'amorce du traitement par le 5-AAS. L'examen physique, l'électrocardiographie et l'imagerie diagnostique permettent d'obtenir des résultats qui indiquent une myocardite, avec ou sans péricardite. L'interruption rapide du traitement par le 5-AAS permet la disparition des symptômes en quelques jours, sans avoir à recourir à un traitement d'appoint. La réintroduction de toute préparation à base de 5-AAS comporte un risque élevé de récurrence de l'inflammation.

Conclusions : Tout patient affichant des douleurs thoraciques, de la dyspnée ou de la fièvre dans les 28 jours suivant l'amorce d'un traitement avec une préparation contenant du 5-AAS doit être considéré comme présentant une inflammation causée par un médicament. Il faut interrompre immédiatement le traitement par le 5-AAS jusqu’à ce que d'autres causes puissent être confirmées ou infirmées. Si l'on ne trouve pas d'autre cause aux symptômes, le traitement par le 5-AAS ne doit pas être recommencé.

Mots clés : acide 5-aminosalicylique, mésalamine, mésalazine, myocardite, péricardite 


\section{INTRODUCTION}

5 Aminosalicylic acid (5-ASA, also known as mesalamine or mesalazine) and its derivatives remain key components in the treatment of ulcerative colitis and in disease-free maintenance therapy. ${ }^{1}$ Although they have a much more limited role in Crohn disease, ${ }^{2}$ 5-ASA compounds are still frequently used in the treatment of newly diagnosed inflammatory bowel diseases (IBDs). The original 5-ASA-containing compound used in IBD treatment was sulfasalazine, which consists of 5-ASA bound to sulfapyridine. Research showed that 5-ASA was the active component of sulfasalazine, which resulted in development of formulations of 5-ASA alone, as a dimer of 5-ASA (olsalazine, available in Canada as Dipentum, Searchlight Pharma, Montréal, Quebec), or as balsalazide, in which 5-ASA is bound to an inactive benzoic acid moiety (not available in Canada). Early use of sulfasalazine exposed a rare but potentially lethal side effect involving inflammation of the heart (myocarditis) or pericardium (pericarditis) or both (myopericarditis). Patients with any of these toxic effects usually present with chest pain or shortness of breath, which may not be recognized as being associated with their IBD treatment. However, if the inflammation leads to extensive pericardial effusion or sufficient myocardial impairment, cardiac output can be detrimentally affected, which results in decreased perfusion to vital organs. The impairment of contractility may be sufficient to warrant intra-aortic balloon pulsation to maintain vital organ perfusion. ${ }^{3}$ Accumulation of sufficient pericardial effusion volume to produce cardiac tamponade may necessitate pericardiocentesis ${ }^{4,5}$ or radical pericardectomy to relieve symptoms. ${ }^{6,7}$ Delays in recognition and treatment may be fatal because of development of cardiogenic shock, which has been reported to occur within $24 \mathrm{~h}$ of presentation and which may be unresponsive to inotropic support. ${ }^{8}$

Recognition of the inflammation and its relationship to 5-ASA therapy is important for preventing subsequent morbidity and mortality. Early use of sulfasalazine raised the possibility that this drug-induced inflammation was caused by the sulfapyridine component of the drug. However, subsequent experience with 5-ASA alone (mesalamine) and balsalazide has suggested that the inflammation is caused by 5-ASA alone. The mechanism for development of the inflammation is as yet unproven, but is thought to be due to 1 of 4 theorized pathways: a direct toxic effect on the myocardium or pericardium, an allergic reaction mediated by immunoglobulin E, a cellmediated hypersensitivity reaction, or a humoral antibody response. ${ }^{6}$ The pathway may not be identical in all patients, since the potential mechanism of cell-mediated hypersensitivity, characterized by eosinophilic infiltration, may not be found in all patients. The development of antibodies against 5-ASA, with cross-reactivity to some component of the pericardium or myocardium, has been theorized as the predominant mechanism. ${ }^{6}$
This side effect of 5-ASA is rare. The literature provides a significant number of single case reports for each of the various agents. The French pharmacovigilance network reviewed reports of adverse reactions to a specific 5-ASA product over 2 years (1993-1994) and found 8 cases of pericarditis and 4 cases of myocarditis, over an estimated volume of 16 million treatment days. ${ }^{9}$ Subsequently, the same French network reviewed all reported cases of toxicity due to 5-ASA from 1984 to 2011 and found 16 cases of pericarditis, 10 cases of myopericarditis, and 8 cases of myocarditis. ${ }^{10}$ Therefore, clinicians providing care to a large number of patients with IBD can expect to see this toxic effect in a certain number of patients.

The current review was undertaken to provide clinicians with information to assist in recognizing the signs and symptoms of 5-ASA-induced cardiac inflammation and determining the appropriate approach to treatment. An electronic database (Embase) was searched for the period 1974 to July 17, 2015, for published descriptions of cases of cardiac inflammation caused by 5-ASA-containing medications. Subject headings used in the search were "salazosulfapyridine" or "mesalamine" or "mesalazine" or "olsalazine" or "balsalazide" and "myocarditis" or "pericarditis". For each subject heading, all subheadings were selected. Relevant articles were selected for review, and the citations referenced in the articles were scrutinized for identification of additional descriptive reports. Articles in any language were included. The following summary of the findings will assist clinicians in considering 5-ASA as the cause of a constellation of symptoms not usually considered to be related to treatment of gastrointestinal disease.

\section{WHAT SHOULD ALERT THE CLINICIAN TO THE POSSIBILITY OF CARDIAC INFLAMMATION?}

There is no symptom, sign, laboratory test, or constellation of symptoms and signs that is pathognomonic for 5-ASA-induced myocardial or pericardial toxicity (Table 1). The patients described in these reports frequently, but not inevitably, presented with fever (Table 1), chest pain, $3,6-8,11,13-17,19,23,24,27,30,31,36-38,40,44-46,48-50,52,53$ and shortness of breath. $7,16,17,24,29,30,32,36,46,52$ The symptom of lassitude or fatigue was also common at the time of presentation. On physical examination, a pericardial rub ${ }^{6,12,14,15,20,23,52,53}$ was sometimes detected, which may have reflected the extent of pericardial involvement. A concurrent pleural rub has been reported, but rarely. ${ }^{23}$

Electrocardiography may show evidence of myocarditis; ST wave depression has been reported, ${ }^{3}$ but ST wave elevation is more common. $8,13,15,23,26,32,33,35,36,44,48,50,51$ Nonspecific findings of flipped $\mathrm{T}$ waves were also evident in some cases. ${ }^{7,11,17,29,30,43,46,49}$ Cardiac echocardiography commonly showed the presence of pericardial effusion. ${ }^{47,12,15-17,20,23,24,26,27,29,37,42,44,52}$ If the pericardial effusion was sufficiently large, cardiac tamponade 
For permission to reprint multiple copies or to order presentation-ready copies for distribution, contact CJHP at cjhpedit@cshp.ca

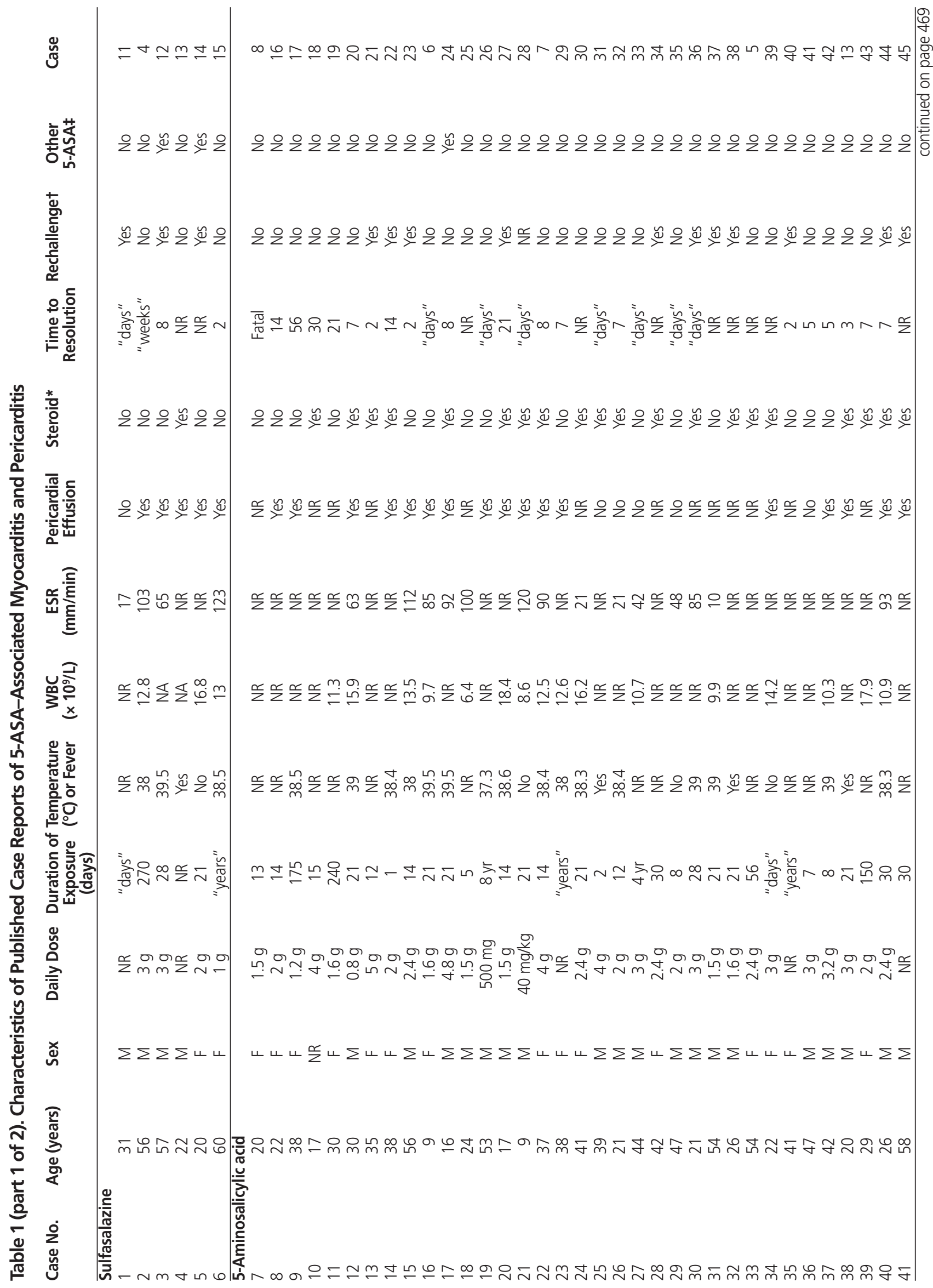




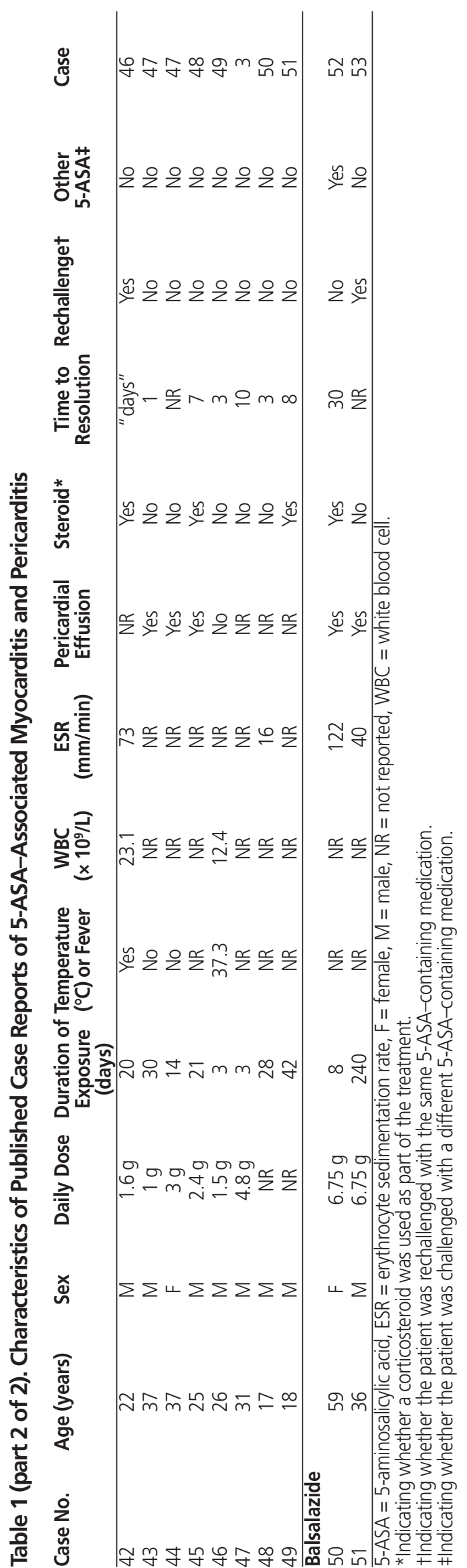

was sometimes noted.5,6 The extent of the myocarditis was sometimes indicated by depressed contractility $8,13,27,31,32,40,43,44,48,50$ shown by echocardiography.

There is no pathognomonic laboratory test that can prove the presence of 5-ASA toxicity. However, most (though not all) patients have exhibited leukocytosis (Table 1). Eosinophilia has sometimes been noted in the leukocyte differential analysis. ${ }^{6,25,33,37,42,44,53}$ Evidence of inflammation was frequently indicated by elevation of the erythrocyte sedimentation rate (Table 1) or C-reactive protein. ${ }^{7}, 12,13,15,31,33-35,37,40,42,45,46,52$ Measurement of myocardial enzymes and proteins frequently showed elevated troponin concentrations. $3,13-15,27,30,32,36,38,40,43,46,48-51$ Elevated $N$-terminal pro-brain natriuretic peptide concentrations have also been found. ${ }^{42,44}$

The presence or absence of any or all of the above symptoms and signs does not confirm the role of 5-ASA in the origin of the condition. The nonspecific findings may also be suggestive of other disease processes, such as ischemic myocardium or other inflammatory conditions of the heart or pericardium. The key distinguishing feature of drug-induced inflammation is the onset of symptoms and signs within a short period after initiation of the 5-ASA therapy. Most of the patients included in this review presented within 28 days of starting the 5-ASA therapy (Table 1). Although there have been reports of presentation after more prolonged exposure, ${ }^{15,26,33,40}$ differentiation of 5-ASA-induced disease from an extraintestinal manifestation of IBD is difficult (see below), and reports of inflammation after prolonged therapy may actually represent the underlying IBD. The clinician should use recent initiation of 5-ASA as the primary clue to the potential for drug-induced disease.

\section{HOW CAN THE CLINICIAN DIFFERENTIATE BETWEEN A DISEASE-INDUCED CONDITION AND A DRUG-INDUCED ADVERSE EFFECT?}

Unfortunately for the clinician attempting to determine the cause of symptoms such as those described in the previous section, IBD can also produce extraintestinal inflammation resulting in myocarditis or pericarditis. ${ }^{54}$ These symptoms can arise from ulcerative colitis ${ }^{55,56}$ or Crohn disease..$^{57}$ The cardiac symptoms may be present at the time of initial presentation of the $\mathrm{IBD}^{5-59}$ or may occur years after diagnosis of either Crohn disease ${ }^{57}$ or ulcerative colitis. ${ }^{60}$ However, the prevalence of myocarditis, pericarditis, or myopericarditis unrelated to 5-ASA in patients with IBD is very low. Only 100 cases of pericarditis associated with ulcerative colitis had been published by $2008 .{ }^{60}$ The relative risk of myocarditis compared with the general population has been described as 8.3 for patients with Crohn disease and 2.6 for those with ulcerative colitis. ${ }^{59}$ However, because the incidence of any of these conditions is very low in the general population, they will occur infrequently in patients with IBD. Thus, it may be difficult to determine whether the 
condition is due to the underlying IBD or to a drug toxicity. If the patient has not yet been exposed to any 5-ASA product, the drug would clearly have no role in causing the condition. However, for patients who are taking a 5-ASA product, it is possible that the symptoms represent a flare of the IBD. ${ }^{60}$ Unfortunately, there is no diagnostic strategy that will differentiate the 2 possible causes, other than stopping the 5-ASA product and monitoring for potential resolution of symptoms.

\section{HOW IS CARDIAC INFLAMMATION TREATED?}

The cornerstone of treatment is abrupt discontinuation of the 5-ASA product. Discontinuation alone usually results in rapid resolution of symptoms, often within only several days (Table 1). No additional treatment may be necessary. Many clinicians have used a short course of corticosteroids in an attempt to reduce the inflammation and resulting symptoms. However, it is not clear whether the corticosteroid treatment shortens the time to resolution of symptoms, because the time course is similar to that in reports of discontinuation only (Table 1). No randomized clinical trials, case series, or observational studies comparing outcomes after corticosteroid treatment versus withholding corticosteroids exist to guide the clinician in predicting any benefit. The use of other antiinflammatory agents has not been extensively reported and should be avoided, given that the symptoms resolve quickly with discontinuation only. However, if symptoms worsen or fail to resolve in the days after discontinuation of the 5-ASA product, the clinician should continue to look for other potential causes.

\section{CAN A PATIENT BE RECHALLENGED WITH A 5-ASA-CONTAINING DRUG?}

Because the patient will usually require ongoing treatment for resolution of the IBD or to maintain IBD remission, there is frequently a desire to restart a 5-ASA product. However, re-exposure to 5-ASA often results in rapid reappearance of the signs and/or symptoms of myocarditis ${ }^{46}$ or pericarditis. ${ }^{45}$ The return of symptoms can occur as rapidly as hours ${ }^{23,24,27}$ to days. ${ }^{11,36,37,40,44}$ However, rechallenge has been tolerated in some cases and allows continued use of a 5-ASA product. ${ }^{12,52}$ The potential use of alternative 5-ASA products has also been explored, with conflicting results. For example, successful use of mesalamine following pericarditis induced by sulfasalazine was described in one case report. ${ }^{12}$ In contrast, using sulfasalazine following intolerance to mesalamine resulted in prompt return of symptoms. ${ }^{24}$ The use of balsalazide following mesalamine-induced inflammation resulted in similar development of pleural effusion within 5 days. ${ }^{14}$ However, sulfasalazine has been tolerated in patients with pericarditis secondary to balsalazide ${ }^{52}$ and to mesalamine. ${ }^{38}$ No clear guidance can be provided regarding the utility or selection of an alternative 5-ASA product following inflammation from any 5-ASA product. If rechallenge with an alternative agent is considered, such a trial should be attempted only in a supervised environment with frequent assessments, because of the potential for rapid recurrence of symptoms.

\section{CONCLUSION}

5-ASA-containing products can produce life-threatening myocarditis and/or pericarditis. Clinicians should be aware of this risk, particularly in the first weeks after initiation of therapy. Patients should be advised to seek medical attention if they experience any symptoms of chest discomfort or shortness of breath. Abrupt discontinuation of the 5-ASA product is usually sufficient to relieve the symptoms and to confirm the diagnosis of drug-induced inflammation. Non-5-ASA-containing therapies should be used for patients who have experienced this drug toxicity, unless extenuating concurrent contraindications prevent other treatments. In such cases, rechallenge should occur only under close and frequent supervision.

\section{References}

1. Dignass A, Lindsay JO, Sturm A, Windsor A, Colombel JF, Allez M, et al. Second European evidence-based consensus on the diagnois and management of ulcerative colitis part 2: current management. J Crohns Colitis. 2012;6(10):991-1030.

2. Dignass A, Van Assche G, Lindsay JO, Lémann M, Söderholm J, Colombel JF, et al.; European Crohn's and Colitis Organisation (ECCO). The second European evidence-based consensus on the diagnosis and management of Crohn's disease: current management. J Crohns Colitis. 2010;4(1):28-62. Erratum in: J Crohns Colitis. 2010;4(3):353 [dosage error in article text].

3. Fleming K, Ashcroft A, Alexakis C, Tzias D, Groves C, Poullis A. Proposed case of mesalazine-induced cardiomyopathy in severe ulcerative colitis. World J Gastroenterol. 2015;21(11):3376-9.

4. Deboever G, Devogelaere R, Holvoet G. Sulphasalazine-induced lupus-like syndrome with cardiac tamponade in a patient with ulcerative colitis. $A m J$ Gastroenterol. 1989;84(1):85-6.

5. Lingutia D, Yarlagadda R, Lakshamanadoss U, Daoud N, Krishnamurthy $\mathrm{M}$, Madan M, et al. Massive pericardial effusion secondary to mesalamine therapy in ulcerative colitis [abstract]. Am J Gastroenterol. 2010;105:S360.

6. Kaiser GC, Milov DE, Erhart NA, Bailey DJ. Massive pericardial effusion in a child following the administration of mesalamine. J Pediatr Gastroenterol Nutr. 1997;25(4):435-8.

7. Oxentenko AS, Loftus EV, Oh JK, Danielson GK, Mangan TF. Constrictive pericarditis in chronic ulcerative colitis. J Clin Gastroenterol. 2002;34(3): 247-51.

8. Kristensen KS, Høegholm A, Bohr L, Friis S. Fatal myocarditis associated with mesalazine. Lancet. 1990:335(8689):605.

9. Marteau P, Nelet F, Le Lu M, Devaux C. Adverse events in patients treated with 5-aminosalicylic acid: 1993-1994 pharmacovigilance report for Pentasa in France. Aliment Pharmacol Ther. 1996;10(6):949-56.

10. Bellet F, Guy C, Guichard I, Cathebras P, Beyens MN, Mounier G, et al. Myocarditis and/or pericarditis under mesalazine treatment: a review of the French pharmacovigilance database [abstract]. Fundam Clin Pharm. 2012;26 Suppl S1:104.

11. Agnholt J, Sørensen HT, Rasmussen STN, Gøtzsche CO, Halkier P. Cardiac hypersensitivity to 5-aminosalicylic acid. Lancet. 1989;1(8647):1135. 
12. Perrot S, Aslangul E, Szwebel T, Gadhoum H, Romnicianu S, Le Jeunne C. Sulfasalazine-induced pericarditis in a patient with ulcerative colitis without recurrence when switching to mesalazine. Int J Colorectal Dis. 2007;22:1119-21.

13. Hun TC, Kumar S, Ponnuswamy K, Kontorinis N, Cheng W, Venugopal K. Severe cardiac complications of aminosalicylic acid drug therapy -2 case reports and literature hightlights [abstract]. J Gastroenterol Hepatol. 2012; 27:106.

14. Sonu I, Wong R, Rothenberg ME. 5-ASA induced recurrent myopericarditis and cardiac tamponade in a patient with ulcerative colitis. Dig Dis Sci. 2013;58(8):2148-50.

15. Qanneta R, Garcia Pardo G, Florit Serra L. Acute pleuropericarditis in a patient with primary Sjögren's syndrome and quiescent ulcerative colitis on longstanding 5-aminosalicylic acid therapy. J Crohns Colitis. 2013; 7(10):e506-7.

16. Jenss H, Becker EW, Weber P. Pericardial effusion during treatment with 5-aminosalicylic acid in a patient with Crohn's disease. Am J Gastroenterol. 1990;85(3):332-3.

17. Dent MT, Ganapathy S, Holdsworth CD, Channer KC. Mesalazine induced lupus-like syndrome. BMJ. 1992:305(6846):159.

18. Heresbach D, Rabot A, Génetet N, Marteau P, Stéphan C, Bretagne JF, et al. Pericardite au cours des maladies inflammatoires intestinales. Complication extra-intestinale ou iatrogène? Gastroenterol Clin Biol. 1994;18(8-9):782-5.

19. Honeybourne D. Mesalazine toxicity. BMJ. 1994;308(6927):533-4.

20. Lin AG, Hine KR. Fever, vasculitic rash, arthritis, pericarditis, and pericardial effusion after mesalazine. BMJ. 1994;308(6921):113.

21. Desmeules J, Vogt N, Loizean S, Angelillo-Scherrer A, Dayer P. [Recurrent pericarditis induced by mesalazine (5-ASA)]. Therapie. 1994;49:359-61. Article in French.

22. Loizeau E. [Ulcerative colitis and pericarditis. The role of mesalazine hypersensitivity]. Rev Med Suisse Romande. 1995;115(11):935-8. Article in French.

23. Gurjal N, Friedenberg F, Friedenberg J, Gabriel G, Kottler M, Levine G. Pleuropericarditis related to the use of mesalamine. Dig Dis Sci. 1996; 41(3):624-6.

24. Sentongo TAS, Piccoli DA. Recurrent pericarditis due to mesalamine hypersensitivity: a pediatric case report and review of the literature. J Pediatr Gastroenterol Nutr. 1998;27(3):344-7.

25. Masutani M, Takahashi K, Matsuda T, Ohira K, Nomura A, Sadaoka K, et al. [Acute myocarditis due to mesalazine in a patient with ulcerative colitis.] Nihon Shokakibyo Gakki Zasshi [Jpn J Gastroenterol]. 1999;96(5):524-9. Article in Japanese.

26. Vayre F, Vayre-Oundjian L, Monsuez JJ. Pericarditis associated with longstanding mesalazine administration in a patient. Int J Cardiol. 1999; 68(2):243-5.

27. Ishikawa N, Imamura T, Nakajima K, Yamaga J, Yuchi H, Ootsuka M, et al. Acute pericarditis associated with 5-aminosalicylic acid (5-ASA) treatment for severe active ulcerative colitis. Intern Med. 2001;40(9):901-4.

28. Mahajan L, Klein A, Wyllie R, Kay M, Applegate K, Sabella C, et al. Atlantoaxial subluxation and pericarditis in a child with Crohn's disease. Am J Gastroenterol. 2001;96(11):3190-1.

29. Merino Rivas JL, Arambarri Segura M, Rodriguez-Navarro CQ, Dronda Núñez F. Pleuropericarditis aguda en paciente con enfremedad de Crohn controlada con tratamiento cronico con mesalazina. Rev Clin Esp. 2002; 202(2):122-3

30. Waite RA, Malinowski JM. Possible mesalamine-induced pericarditis: case report and literature review. Pharmacotherapy. 2002;22(3):391-4.

31. García-Morán S, Sáez-Royuela F, Pérez-Alvarez JC, Gento E, Téllez J. Myopericarditis and mitral insufficiency associated with ulcerative colitis treated with mesalazine. Inflamm Bowel Dis. 2006;12(4):334-5.

32. Doganay L, Akinci B, Pekel N, Simsek I, Akpinar H. Mesalazine-induced myopericarditis in a patient with ulcerative colitis. Int J Colorectal Dis. 2006;21(2):199-200.

33. Hermida JS, Six I, Jarry G. Drug-induced pericarditis mimicking Brugada syndrome. Europace. 2007;9(1):66-8.

34. Stelts S, Taylor MH, Nappi J, Van Bakel AB. Mesalamine-associated hypersensitivity myocarditis in ulcerative colitis. Ann Pharmacother. 2008; 42(5):904-5.
35. Husein B, Cooksley T, Iqbal J, Akhtar M. Myocarditis and mesalazine. Gastroenterol Today. 2009;19(4):94-5.

36. Triantafillidis JK, Cheracakis P, Mylonaki M, Georgopoulos F, Panteris V, Malgarinos G, et al. Myocarditis due to mesalamine treatment in a patient with ulcerative colitis: favorable outcome after infliximab treatment. Ann Gastroenterol. 2009;22(1):624.

37. Bernal-Sprekelsen JC, de las Marinas MD, Salvador A, Landete FJ, Morera FJ. Recurrent pericarditis in a patient with ulcerative proctitis due to mesalazine suppositories. Int J Colorectal Dis. 2010;25(9):1143-4.

38. Freeman HJ, Salh B. Recurrent myopericarditis with extensive ulcerative colitis. Can J Cardiol. 2010;26(10):549-50.

39. Martin M, Santamarta E, de la Iglesia JM, Saiz A. Myopericarditis in a patient with ulcerative colitis treated with mesalazine. Med Clin (Barc). 2010; 134(1):40-4.

40. Merceron O, Bailly C, Khalil A, Pontnau F, Hammoudi N, Dorent R, et al. Mesalamine-induced myocarditis. Cardiol Res Pract. 2010;2010:930190.

41. Sierra Ausín M, Rascarachi G, Díez Rodríquez R, Arias Rodríquez L, Del Pozo Maroto E, Muñoz Núñez F. [Mesalazine-induced acute pericarditis]. Gastroenterol Hepatol. 2010;33(4):338-9. Article in Spanish.

42. Sposato B, Allegri MP, Riccardi MP, Chigiotti S, Nencioni C, Ricciardi B, et al. Mesalazine-induced multi-organ hypersensitivity. Clin Drug Investig. 2010; 30(6):413-7.

43. Liu Y, Ye J, Zhu Z, Chen W, Sun Y.Myocarditis due to mesalamine treatment in a patient with Crohn's disease in China. Turk J Gastroenterol 2012; 23(3):304-6.

44. Park EH, Kim BJ, Huh JK, Jeong EH, Lee SH, Bang KB, et al. Recurrent mesalazine-induced myopericarditis in a patient with ulcerative colitis. $J$ Cardiovasc Ultrasound. 2012;20(3):154-6.

45. Syal G, Sethi S, Zafar S, Aduli F. Mesalamine induced pericarditis [abstract]. Am J Gastroenterol. 2012;107 Suppl:S516.

46. Sabatini T, Filippini A, Nicosia F, Preti S, Bertoli M. Recurrence of myocarditis after mesalazine treatment for ulcerative colitis: a case report. Inflamm Bowel Dis. 2013;19(3):E46-8.

47. Calafat $\mathrm{M}$, Mañosa $\mathrm{M}$, Cabré E, Domènech E. [Acute pericarditis associated with oral or topical mesalazine therapy in patients with ulcerative colitis]. Gastroenterol Hepatol. 2014;37(4):254-5. Article in Spanish.

48. Malakouti M, Garapati K, Randall C. Myopericarditis in a patient with ulcerative colitis on mesalamine and prednisone: case report and review of literature [abstract]. Am J Gastroenterol. 2014;109 Suppl:438.

49. Roczek M, Polak L, Zielinska M, Chizynski K. Myopericarditis in a patient with ulcerative colitis treated with mesalamine. Case report and review of the literature. J Card Cases. 2014;10:104-7.

50. Nair AG, Cross RR. Mesalamine-induced myopericarditis in a paediatric patient with Crohn's disease. Cardiol Young. 2015;25:783-6.

51. Sorleto M, Dürrwald S, Wiemer M. Mesalazine-induced myopericarditis in a patient with a recent diagnosis of Crohn's disease: apropos of a case. Case Rep Cardiol. 2015;2015:728310.

52. Adhiyaman V, Vaishnavi A, Froese $S$. Hypersensitivity reaction to balsalazide. BMJ. 2000;320(7235):613.

53. Coman RM, Glover SC, Gjymishka A. Febrile pleuropericarditis, a potentially life-threatening adverse event of balsalazide-case report and literature review of the side effects of 5-aminosalicylates. Expert Rev Clin Immunol. 2014;10(5):667-75.

54. Abu-Hijleh M, Evans S, Aswad B. Pleuropericarditis in a patient with inflammatory bowel disease: a case presentation and review of the literature. Lung. 2010;188(6):505-10.

55. Sarrouj BJ, Zampino DJ, Cilursu AM. Pericarditis as the initial manifestation of inflammatory bowel disease. Chest. 1994;106(6):1911-2

56. Orii S, Chiba T, Nakadate I, Fujiwara T, Ito N, Ishii M, et al. Pleuropericarditis and disseminated intravascular coagulation in ulcerative colitis. J Clin Gastroenterol. 2001;32(3):251-4.

57. Hyttinen L, Kaipiainen-Seppänen O, Halinen M. Recurrent myopericarditis in association with Crohn's disease. J Intern Med. 2003;253(3):386-8.

58. Nishtar SS, Rajendran R, Mathur A, Khattak S. Fulminant myocarditis: a rare but life-threatening association of Crohn's disease. Emerg Med J. 2008; 25(5):314-5. 
59. Oh IS, Choi CH, Park JH, Kim JW, Cha BK, Do JH, et al. A case of acute myocarditis as the initial presentation of Crohn's disease. Gut Liver. 2012; 6(4):512-5.

60. Cappell MS, Turkieh A. Chronic pericarditis and pericardial tamponade associated with ulcerative colitis. Dig Dis Sci. 2008;53(1):149-54.

Glen Brown, PharmD, FCSHP, BCPS(AQ), BCCCP, is with the Pharmacy, St Paul's Hospital, Vancouver, British Columbia. He is also an Associate Editor with the Canadian Journal of Hospital Pharmacy.
Competing interests: None declared.

Address correspondence to:

Dr Glen Brown

Pharmacy

St Paul's Hospital

1081 Burrard Street

Vancouver BC V6Z 1Y6

e-mail: gbrown@providencehealth.bc.ca

Funding: None received.

\section{CSHP's 2017 Professional Practice Conference Keynote Speaker: Timothy Caulfield}

Presented by:

\section{S. SANDOZ}

a Novartis company

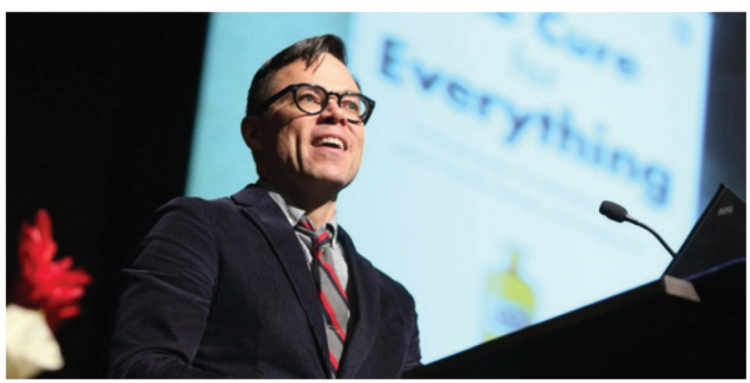

Professor of Health Law and Science Policy | Author of Is Gwyneth Paltrow Wrong About Everything?
Twitter:

@CaulfieldTim

Professor Timothy Caulfield is an unrivaled communicator who debunks myths and assumptions about innovation in the health sector-from research on stem cells to diets to alternative medicine-for the benefit of the public and decision-makers. He is a Canada Research Chair in Health Law and Policy, and a Professor in the Faculty of Law and the School of Public Health at the University of Alberta. He has been the Research Director of the Health Law Institute at the University of Alberta since 1993.

He writes frequently for the popular press on a range of health and science policy issues and is the author of The Cure for Everything: Untangling the Twisted Messages about Health, Fitness and Happiness, and his most recent book, Is Gwyneth Paltrow Wrong About Everything?: When Celebrity Culture and Science Clash. 